\title{
Power Quality Recommendations in Mushroom Farm
}

\author{
Thangavel $\mathbf{R}$
}

\begin{abstract}
Mushroom development is one of the most gainful agribusiness that can be begun with least speculation and space. Mushroom cultivating in India is developing consistently as an elective wellspring of salary. Here is the finished direction on paddy straw mushroom, shellfish mushroom and catch mushroom generation in India. This paper proposes power quality recommendations in small scale mushroom farm located in Sulur, Coimbatore
\end{abstract}

Keywords: power quality, energy audit, mushroom farm, energy recommendations

\section{INTRODUCTION}

Mushrooms have been perceived by Food and Agriculture Association (FAO) as nourishment thing adding to the protein supplement to the eating regimen of creating nations like India, where there is substantial reliance on oat eats less carbs. The noteworthy highlight of mushroom is that this nutritious and classy nourishment is developed altogether from squander items and changes over a wide range of horticultural and modern waste into substrate on which the development of mushroom is bolstered. In the wake of collecting the mushroom, the strong leftover left is natural fertilizer with regular supplements to further improve the dirt. Notwithstanding changing over the loss into significant item, it improves the pay and gives extra profitable work to the makers. Keeping in see the expanding request of mushroom because of globalization and opening of the economy. Along these lines, this article is an endeavor to investigate the present situation of the mushroom business. Employment, Energy and Equipment are the major operating costs of any business. Energy cost is top rated. In this manuscript power quality recommendations in small scale mushroom farm located in Sulur, Coimbatore is presented. The recommendations are based on the present operating status of the plant.

\section{LOAD DETAILS}

The farm is situated at sulur, Coimbatore. The sanctioned demand is $450 \mathrm{kVA}$, power provider is TANGEDCO. The details of power are shown in Table 1 and Table 2 describes existing power facility available in the farm.

Revised Manuscript Received on November 06, 2019.

R. Thangavel, Assistant Professor, Dept. of EEE, Faculty of Engineering, Karpagam Academy of Higher Education, Coimbatore, India. Email: thangaveleeekit@gmail.com
Table 1 Electricity Details

\begin{tabular}{|c|c|c|c|}
\hline $\begin{array}{c}\text { Source of Power } \\
\text { Supply }\end{array}$ & $\begin{array}{c}\text { Sanctioned } \\
\text { Demand }\end{array}$ & $\begin{array}{c}\text { Billed } \\
\text { Demand, } \\
\text { kVA }\end{array}$ & $\begin{array}{c}\text { Average } \\
\text { Power } \\
\text { Factor }\end{array}$ \\
\hline TANGEDCO & 450 KVA & 405 KVA & 0.85 \\
\hline
\end{tabular}

Table 2 Existing Power Facility

\begin{tabular}{|l|c|c|}
\hline \multicolumn{1}{|c|}{ Description } & Nos. & Rating \\
\hline Transformer (kVA) & 1 & $800 \mathrm{KVA}$ \\
\hline DG (kVA) & 0 & 3 X 500 KVA \\
\hline Capacitors (kVAr - HT/LT) & LT & NIL \\
\hline M V panel & 1 & \\
\hline Distribution Boards & 3 & \\
\hline
\end{tabular}

\section{ENERGY STUDY AND RECOMMENDATIONS}

The key equipments in mushroom farms are usually cooling unit, cooling racks, boiler, centrifugal blowers, compost filling line, bag filling machine, DG set etc. may be required. Some of the equipments ate optional. The complete energy study was taken in the farm for three days. The details of study and recommendation were given as per the present condition of the farm.

\section{A. Transformer Incomer}

Initially Transformer Incomer at MV Panel data was taken and shown in Table 3.

Table 3 Transformer Incomer data

\begin{tabular}{|l|c|}
\hline Parameters & Without Capacitor \\
\hline Voltage & 409.7 \\
\hline Current & 355.2 \\
\hline Power in KW & 199.8 \\
\hline Power Factor & $0.77 \mathrm{lag}$ \\
\hline $\mathrm{V}_{\mathrm{THD}} \%$ & $2.8 \%$ \\
\hline $\mathrm{I}_{\mathrm{THD}} \%$ & $36,7 \%$ \\
\hline
\end{tabular}

The Total voltage harmonics $\left(\% \mathrm{~V}_{\text {thd }}\right)$ is $2.8 \%$ without capacitors are within the limit as specified in the IEEE 519-1992 .i.e 5\%. The Total Current harmonics (\% $\left.\mathrm{I}_{\text {thd }}\right)$ is $36.7 \%$ without capacitors Excess the limit of $8 \%$. The instantaneous power factor is 0.73 to 0.78 lagging without capacitor. The Power factor maintained at Transformer is varying from 0.73 to 0.84 .

\section{Recommendation}

Connect $150 \mathrm{KVAR}$ APFC De tune harmonic filter with 7\% block reactor at M V Panel to maintain the unity power factor or Connect 100 A 3Phase 4 Wire Active harmonic filter at M V Panel 
Power Quality Recommendations in Mushroom Farm

\section{B. Sub Switch Board 1}

Table 4 SSB 1 Data

\begin{tabular}{|l|c|}
\hline \multicolumn{1}{|c|}{ Parameters } & Readings \\
\hline Connected Capacitor & NIL \\
\hline Cable size & $\begin{array}{r}\text { Runs of 3 1/2 C,300 SQMM } \\
\text { Aluminum XLPE }\end{array}$ \\
\hline Voltage & 409.2 \\
\hline Current & 236.2 \\
\hline Power in KW & 119.55 \\
\hline Power Factor & 0.68 lagg \\
\hline $\mathrm{V}_{\mathrm{THD}} \%$ & $1.9 \%$ \\
\hline $\mathrm{I}_{\mathrm{THD}}$ & $23.9 \%$ \\
\hline
\end{tabular}

Table 4 shows the details of Sub Switch Board (SSB) 1 at MV Panel. The voltage harmonics (\%V thd ) is $1.9 \%$ are within the limit as specified in the IEEE 519-1992.i.e 5\%. The Total Current harmonics ( $\% \mathrm{I}_{\text {thd }}$ ) is $23.9 \%$ More than the limit of as specified in the IEEE 519-1992.i.e $8 \%$. The instantaneous power factor is 0.68 lagging without capacitor.

\section{Recommendation}

From the above table Harmonics Amplified by VFD unit. To Avoid Harmonic Amplification Connect 50 KVAR Detune passive filter $7 \%$ reactor $+525 \mathrm{~V}$ passive filter at SSB level.

\section{Sub Switch Board 2}

In SSB 2, the voltage harmonics (\%V thd ) is $1.9 \%$ are within the limit as specified in the IEEE 519-1992.i.e 5\%. The Total Current harmonics (\% I thd) is $31.9 \%$ More than the limit of as specified in the IEEE 519-1992.i.e $8 \%$. The instantaneous power factor is 0.99 lagging without capacitor. The details of SSB 2 shown in table 5.

Table 5 SSB 2

\begin{tabular}{|l|c|}
\hline \multicolumn{1}{|c|}{ Parameters } & Readings \\
\hline $\begin{array}{l}\text { Connected } \\
\text { Capacitor }\end{array}$ & NIL \\
\hline Cable size & $\begin{array}{c}\text { 1Runs of 3 1/2 C, } \\
\text { 240 SQMM } \\
\text { Aluminum XLPE }\end{array}$ \\
\hline Voltage & 406.2 \\
\hline Current & 16.30 \\
\hline Power in KW & 11.40 \\
\hline Power Factor & 0.99 lagg \\
\hline $\mathrm{V}_{\mathrm{THD}} \%$ & $1.9 \%$ \\
\hline $\mathrm{I}_{\mathrm{THD}} \%$ & $31.9 \%$ \\
\hline
\end{tabular}

\section{Recommendation}

From the table 5 Harmonics Amplified by VFD unit. To Avoid Harmonic Amplification Connect 50 KVAR Detune passive filter $7 \%$ reactor $+525 \mathrm{~V}$ passive filter at SSB level.

\section{Sub Switch Board 3}

In SSB 3 (Table 6), The voltage harmonics $\left(\% \mathrm{~V}_{\text {thd }}\right)$ is 1.9 $\%$ are within the limit as specified in the IEEE 519-1992.i.e $5 \%$. The Total Current harmonics $\left(\% \mathrm{I}_{\text {thd }}\right)$ is $30.9 \%$. More than the limit of as specified in the IEEE 519-1992.i.e $8 \%$. The instantaneous power factor is 0.94 lagging without capacitor.

Table 6 SSB 3

\begin{tabular}{|l|l|}
\hline \multicolumn{1}{|c|}{ Parameters } & \multicolumn{1}{c|}{ Readings } \\
\hline Connected Capacitor & NIL \\
\hline Cable size & $\begin{array}{l}\text { 2Runs of 3 1/2 C,300 SQMM } \\
\text { Aluminum XLPE }\end{array}$ \\
\hline Voltage & 404.9 \\
\hline
\end{tabular}

\begin{tabular}{|l|l|}
\hline Current & 29.79 \\
\hline Power in KW & 18.08 \\
\hline Power Factor & 0.94 lagg \\
\hline V.THD \% & $1.9 \%$ \\
\hline I THD \% & $30.9 \%$ \\
\hline
\end{tabular}

\section{Recommendation}

From the above table Harmonics Amplified by VFD unit. To Avoid Harmonic Amplification Connect 50 KVAR Detune passive filter $7 \%$ reactor $+525 \mathrm{~V}$ passive filter at SSB level.

\section{CONCLUSION}

Improving working parameters of the farm towards wellbeing also, improved effectiveness. The before mentioned suggestions are a portion of the better purposes of vitality economy measures being attempted and to be attempted in the farm. The above measures are planned for running existing apparatuses to the most extreme conceivable adequacy. We need to diminish the avoidable misfortunes to the most extreme in the transmission of vitality from one state to other in the gear and we are attempted to match existing productivity of types of gear to suit the procedure. At the same time we attempt to improve the current encompassing conditions encompassing the types of gear to suit and solace the supplies, that they can give better yield to process.

\section{REFERENCES}

1. K. Balachander, A. Amudha, "Energy Economy Recommendations in Textile Mill", International Journal of Engineering and Advanced Technology, Volume-8 Issue-4, April 2019, pp.168-176.

2. K. Balachander, A. Amudha, "Energy Saving Measures in Textile Mill", International Journal of Innovative Technology and Exploring Engineering, Volume-8 Issue-8, June 2019, pp.2026-2032.

3. Hand book on Canadian Ind. Program for Energy Conservation, "Energy Saving Tool box - An Energy Audit Manual \& Tool", Oct. 2015.

4. S. U. Kulkarni, K Patil., "Energy Audit of an Industrial Unit - A Case Study", Int. Journal of Emerging Science and Engg. Vol. 2(2), pp. 22-26, Nov. 2013

5. M.B. Raghav1, M. S. Srijaa, G. S. Rao, K. N. Bhavya and Y. Suchitra, "Energy Conservation and Audit - A Case Study", Int. Journal of Adv. Research in Electrical, Electronics and Instrumentation Engg. Vol. 2 (10), pp. 4957-4966, October 2013.

6. Neetha J., Mohandas R., Suja C R., "Energy Saving Mechanism Using Variable Frequency Drives", Int. J of Emerging Tech. and Advanced Engg. Volume 3 (3), pp. 784-790, Mar 2013

7. P. G. Kini, R. C. Bansal, "Energy Eff. in Industrial Utilities, Energy Management Systems", ISBN: 978-953-307-579-2, 2011.

8. Guide book for Nat. Certification Examination for Energy Managers and Energy Auditors. (a) Book 1 - Energy Efficiency in Electrical, Utilities, (b) Book 2 - Energy Efficiency in Thermal Utilities . (c) Book 3 - Energy Performance Assessment for Equipment and Utility Systems. (d) Book 4 - General Aspects of Energy Management and Energy Audit.

9. Bunkley. Nick ,'Joseph Juran, 103, Pioneer in Quality Control Dies", NY Times, March 3, 2008.

10. Journal of Food Engg. P.C. Panchariya, D.Popovic, A.L. Sharma Volume 52, Issue 4, May 2002, Pages 349-357

11. L.C. Witte, P. Schmidt, Dr. Brown, "Ind. Energy Management \& Utilization" Hemisphere publishing corp., NY, USA, 1987.

12. L.C. Witte, P.Schmidt, Dr. Brown, "Ind. Energy Mangt. and Utilization" Hemisphere publishing corp., NY, USA, 1987. 


\section{AUTHORS PROFILE}

Thangavel R,Received The Bachelor Degree In Electrical And Electronics Engineering From Kalaignar Karunanithi Instituite Of Technology, Coimbatore In 2013. He Acquired Master Of

Engineering In Power System, From Anna University Coimbatore In 2016. He Is Working As An Assistant Professor In Karpagam Academy Of Higher Education, Karpagam University, India. He Has Totally Around 2 Years Of Teaching Experience And 2 Years Of Industry Experience. He Has Published Various National And International Journal Papers And Conference Proceedings. 